\title{
Cross-border shopping from small to large countries
}

\author{
Nielsen, Søren Bo
}

Document Version

Final published version

Publication date:

2002

\section{License}

CC BY-NC-ND

Citation for published version (APA):

Nielsen, S. B. (2002). Cross-border shopping from small to large countries.

Link to publication in CBS Research Portal

\section{General rights}

Copyright and moral rights for the publications made accessible in the public portal are retained by the authors and/or other copyright owners and it is a condition of accessing publications that users recognise and abide by the legal requirements associated with these rights.

\section{Take down policy}

If you believe that this document breaches copyright please contact us (research.lib@cbs.dk) providing details, and we will remove access to the work immediately and investigate your claim. 


\section{Center for Law, Economics and Financial Institutions at CBS}

LEFIC WORKING PAPER 2002-06

CROSS-BORDER SHOPPING FROM SMALL TO LARGE COUNTRIES

Søren Bo Nielsen

www.cbs.dk/LEFIC 


\title{
Cross-border shopping from small to large countries
}

\author{
Søren Bo Nielsen \\ Copenhagen Business School and EPRU
}

May 2002

\begin{abstract}
Contrary to predictions of theoretical models, there are many examples in the real world of cross-border shopping from small to large countries. We demonstrate that a sufficient wedge between marginal costs of public funds in small and large countries can explain this phenomenon.
\end{abstract}

JEL classification: H87, H20

Keywords: cross-border shopping, commodity taxation, MCPFs

${ }^{*}$ Forthcoming, Economics Letters. The activities of Economic Policy Research Unit are financed by a grant from The Danish National Research Foundation. Address of author: Department of Economics, Copenhagen Business School, Solbjerg Plads 3, DK-2000 Frederiksberg, Denmark; tel.: (+45) 381525 96, fax: (+45) 381525 76, e-mail: sbn.eco@cbs.dk. 


\section{Introduction}

The international effects of taxation as well as the external constraints on tax policy in individual countries have come to the fore over the last decade or so. In particular, there has been great interest in tax competition, i.e. national governments competing for capital, labor or sales of goods via their capital income, labor income and consumption tax policies. By now, the literature is well established and understood, but sometimes the predictions of the literature are not quite borne out in practice.

One example of this is found in the literature on commodity tax competition and cross-border shopping. In the famous model by Kanbur and Keen (1993) as well as in subsequent work by Trandel (1994), Wang (1999) and Nielsen (2001), cross-border shopping is modelled in a two-country framework with some size asymmetry between the two countries. ${ }^{1}$ In Kanbur and Keen's model as well as those of Trandel and Wang one country has a bigger population density; in Nielsen's model, one country is larger than the other in geographical extent. Either way, one country has more inhabitants than the other, and cross-border shopping is predicted as running from the large country to the small. The reason for this is that at given taxes in the two countries, potential crossborder shopping consumers make up a greater percentage of inhabitants in the small country than in the large country. Thus, the smaller country is led to attach a greater weight to luring border crossers than the large country and therefore ends up setting the lower commodity tax rate.

In the real world, there are many examples of smaller countries setting relatively low value added and excise taxes, thus attracting border shoppers from bigger neighboring countries. For instance, Germans shopping in Belgium and the Netherlands are induced to do so because of low excise taxes in the smaller 'low' countries. Such examples conform well to the predictions of the theory. However, there are also many examples of crossborder shopping running in the 'wrong' direction, that is from small to large countries. Cross-border shopping from Canada to the US and from Denmark to Germany are a few examples.

This paper extends previous work in the area of commodity taxation and cross-border shopping by providing one possible explanation for the puzzle of cross-border shopping from small to large countries. We demonstrate that provided smaller countries feature sufficiently larger marginal costs of public funds, their governments will select commod-

\footnotetext{
${ }^{1}$ In Haufler (1996) there is no size asymmetry, but countries differ in their preferences for public vs. private goods.
} 
ity taxes so that cross-border shopping from small to large countries ensues. Greater marginal costs of public funds may derive from citizens in the smaller countries valuing public goods more than citizens in larger countries, or from other available taxes being more distortionary in the small countries. Whatever the reason, it may be enough to reverse the direction of cross-border shopping.

Section 2 sets up a simple model of commodity taxation and cross-border shopping, while section 3 establishes the central claim of the paper.

\section{The model}

Our model, building on that in Nielsen (2001), has two countries, together represented by the interval $[-1,1]$. Population is evenly spread out with a density of unity in both countries. The larger of the two extends from -1 to some border parameter $b>0$, while the smaller one extends from $b$ to 1 . Hence, population sizes are $1+b$ and $1-b$, respectively. This way of modelling the location of population implies variation in the distance to the border, and this has the consequence, as we shall see below, that some individuals engage in cross-border shopping, while others shop at home.

There is one (composite) good in the model. Each individual purchases one unit of the good, when his reservation price exceeds the price of the good. Reservation prices in the large and the small country are denoted by $V$ and $v$, respectively. We shall assume that these reservation prices are high enough that for relevant tax-inclusive commodity prices in the two countries, all individuals will indeed wish to purchase the commodity.

With a constant number of individuals and with the guarantee that all individuals will purchase one unit of the good, we may as well ignore the production cost of the good and set it equal to zero. Commodity taxes are specific taxes, and they are levied at the rates $T$ in the large and $t$ in the small country. Goods prices are then simply the relevant tax rates. For an individual to travel to the border to purchase the good abroad, a transportation cost of $d$ per unit distance travelled ${ }^{2}$ is incurred. While some individuals may choose this option, the rest purchase the good in the place of residence. An individual in the large country will purchase the good at the border, if the surplus obtained by doing so, $V-t-d S$, where $S$ stands for the necessary distance travelled, exceeds the surplus from buying at home, $V-T$. Hence, those with a distance $S \square S^{*}=(T-t) / d$ will opt for cross-border shopping (for $T>t$; if $T \square t$, no-one will do so). Similarly, citizens in

\footnotetext{
${ }^{2}$ The cost includes the return part of the trip as well.
} 
the small country for whom the distance to the border $s$ fulfils $s \square s^{*}=(t-T) / d$ will choose to shop abroad (again, if $t \square T$, no-one will).

With an open border, the two countries will have an incentive to undercut each other in order to capture tax revenue from foreigners who are led to shop across the border.

Incorporating cross-border shopping, the number of residents of the large country shopping abroad is $(T-t) / d$, if $T>t$. If on the contrary $T<t,(t-T) / d$ small country individuals shop in the large country. Hence, tax revenues in the large and small countries amount to, respectively,

$$
R(T, t)=T\left[1+b+\frac{t-T}{d}\right], \quad r(t, T)=t\left[1-b+\frac{T-t}{d}\right]
$$

We now imagine that the two countries choose their taxes in a noncooperative manner so as to maximize national welfare. The tax system in either country (which disposes of other taxes than the commodity taxes under consideration) is characterized by a given marginal cost of public funds (MCPF), $\rho$ in the large country and $\rho^{*}$ in the small. Below, these MCPFs will be allowed to differ.

A welfare measure can now be constructed as the sum of tax revenue, weighted by the MCPF, and private surplus. The latter measures, as a sum over the population, the difference between the value of the good to consumers and their total cost of acquiring it. Two situations can be distinguished: one, where cross-border shopping runs from the large to the small country; and one, where the direction is reversed. In the former case, we may write welfare in the large country, $W$, as follows:

$$
W=(V-T)\left[1+b-\frac{T-t}{d}\right]+\int_{0}^{(T-t) / d}(V-t-d s) d s+\rho R(T, t)
$$

Here, the first term represents private surplus on the part of those individuals who do not engage in cross-border trade. The second term yields private surplus for those that do. Finally, the third term is tax revenue weighted by the MCPF $(R(T, t)$ is given in (1) above). For the small country

$$
w=(V-t)(1-b)+\rho^{*} r(t, T)
$$

i.e. a simpler sum of private surplus and weighted tax revenue. Again, $r(t, T)$ is given in (1). 
If instead cross-border shopping runs in the opposite direction from the small to the large country, welfare expressions become

$$
w=(V-t)\left[1-b-\frac{t-T}{d}\right]+\int_{0}^{(t-T) / d}(V-T-d s) d s+\rho^{*} r(t, T)
$$

and

$$
W=(V-T)(1+b)+\rho R(T, t)
$$

for the small and large countries, respectively.

\section{MCPFs and the direction of cross-border shopping}

We now wish to derive a condition on the MCPFs in the two countries which enables crossborder trade in the unexpected direction from the small to the large country. Observe first that the choice of commodity tax in one country impacts national welfare in the other. Hence, we shall assume commodity taxes to be set strategically and suppose that the resulting commodity tax equilibrium is a Nash equilibrium. ${ }^{3}$

Rewrite the expression for $w$ in (4) as

$$
w=\left(V+\left(\rho^{*}-1\right) t\right)\left[1-b-\frac{t-T}{d}\right]+\frac{t-T}{d}\left[V-\frac{t+T}{2}\right]
$$

Using this and the expression for $W$ in (5) we get the following reaction functions from welfare maximization,

$$
T=\frac{t}{2}+\frac{(\rho-1)(1+b) d}{2 \rho}
$$

and

$$
t=\frac{\left(\rho^{*}-1\right) T}{2 \rho^{*}-1}+\frac{\left(\rho^{*}-1\right)(1-b) d}{2 \rho^{*}-1}
$$

From the reaction functions we can obtain Nash equilibrium taxes

$$
T=\frac{d}{\left(3 \rho^{*}-1\right) \rho}\left[(1-b) \rho\left(\rho^{*}-1\right)+(1+b)(\rho-1)\left(2 \rho^{*}-1\right)\right]
$$

and

$$
t=\frac{d}{\left(3 \rho^{*}-1\right) \rho}\left[(1-b) 2 \rho\left(\rho^{*}-1\right)+(1+b)(\rho-1)\left(\rho^{*}-1\right)\right]
$$

\footnotetext{
${ }^{3}$ The commodity tax equilibria in Kanbur and Keen (1993), Trandel (1994), Haufler (1996) and Nielsen (2001) are Nash equilibria, while Wang (1999) and Hvidt and Nielsen (2001) study Stackelberg equilibria.
} 
If cross-border trade is to run from the small to the large country as posited, then the large country must have the smaller tax, $T<t$, implying from (8) and (9) that

$$
\frac{\left(\rho^{*}-1\right) \rho}{(\rho-1) \rho^{*}}>\frac{1+b}{1-b}
$$

This requirement will be fulfilled, if for given $b>0$ the MCPF in the small country exceeds that in the large country by a sufficient margin. For example, let $b=0.2$ and the MCPF of the the large country be equal to 1.2. Then if the MCPF of the small country exceeds $4 / 3$, cross-border shopping will run from the small to the large country.

The reader may, by the way, convince herself that if the inequality (10) holds with the inequality sign reversed, then the model generates a Nash equilibrium with the higher tax in the large country and hence cross-border trade from the large to the small country, just as in previous models in the literature. So if the MCPF in the small country lies below that in the large country, or exceeds it by only little, then cross-border trade will run in the usual direction.

\section{Conclusions}

As empirical contradictions to previous results in the literature on commodity taxation and cross-border shopping there are many examples around the world of cross-border shopping from a small to a large country. We have demonstrated that it is possible to generate cross-border shopping from small to large countries in a simple model of crossborder trade, where the marginal cost of public funds in the small country exceeds that in the large country by a sufficient amount. 


\section{References}

Haufler, A., 1996, Tax coordination with different preferences for public goods: Conflict or harmony of interest? International Tax and Public Finance 3, 5-28.

Hvidt, M. and S. B. Nielsen, 2001, Non-cooperative vs. minimum-rate commodity taxation, German Economic Review 2, 315-326.

Kanbur, R. and M. Keen, 1993, Jeux sans frontières: Tax competition and tax coordination when countries differ in size, American Economic Review 83, 877-892.

Nielsen, Soren Bo, 2001, A simple model of commodity taxation and cross-border shopping, Scandinavian Journal of Economics 103, 599-623.

Trandel, G.A., 1994, Interstate commodity tax differentials and the distribution of residents, Journal of Public Economics 53, 435-457.

Wang, Y-Q., 1999, Commodity taxes under fiscal competition: Stackelberg equilibrium and optimality, American Economic Review 89, 974-981. 